NBER WORKING PAPER SERIES

\title{
REDISTRIBUTION OF LOCAL LABOR MARKET SHOCKS THROUGH FIRMS' INTERNAL NETWORKS
}

\author{
Xavier Giroud \\ Holger M. Mueller
}

Working Paper 22396

http://www.nber.org/papers/w22396

\author{
NATIONAL BUREAU OF ECONOMIC RESEARCH \\ 1050 Massachusetts Avenue \\ Cambridge, MA 02138 \\ July 2016
}

Previously circulated as "Redistribution of Local Demand Shocks through Firms' Internal Networks." We would like to thank Scott Baker, Itamar Drechsler, Xavier Gabaix, Ben Keys, Theresa Kuchler, Andres Liberman, Ulrike Malmendier, Atif Mian, Daniel Paravisini, Thomas Philippon, Alexi Savov, Johannes Stroebel, Amir Sufi, Stijn van Nieuwerburgh, and seminar participants at NYU and the 2016 NBER SI for helpful comments. We are grateful to Manuel Adelino and Albert Saiz for providing us with data. Any opinions and conclusions expressed herein are those of the authors and do not necessarily represent the views of the U.S. Census Bureau or the National Bureau of Economic Research. All results have been reviewed to ensure that no confidential information is disclosed.

NBER working papers are circulated for discussion and comment purposes. They have not been peer-reviewed or been subject to the review by the NBER Board of Directors that accompanies official NBER publications.

(C) 2016 by Xavier Giroud and Holger M. Mueller. All rights reserved. Short sections of text, not to exceed two paragraphs, may be quoted without explicit permission provided that full credit, including $\odot$ notice, is given to the source. 
Redistribution of Local Labor Market Shocks through Firms’ Internal Networks

Xavier Giroud and Holger M. Mueller

NBER Working Paper No. 22396

July 2016, Revise July 2016

JEL No. E24,E32,G31,J23,J63

\begin{abstract}
$\underline{\text { ABSTRACT }}$
Local labor market shocks are difficult to insure against. Using confidential micro data from the U.S. Census Bureau's Longitudinal Business Database, we document that firms redistribute the employment impacts of local demand shocks across regions through their internal networks of establishments. During the Great Recession, the massive decline in house prices caused a sharp drop in consumer demand, leading to large employment losses in the non-tradable sector. Consistent with firms smoothing out the impacts of these shocks across regions, we find large elasticities of non-tradable establishment-level employment with respect to house prices in other counties in which the firm has establishments. At the same time, establishments of firms with larger regional networks exhibit lower employment elasticities with respect to local house prices in the establishment's own county. To account for general equilibrium adjustments, we aggregate non-tradable employment at the county level. Similar to what we found at the establishment level, we find that non-tradable county-level employment responds strongly to local demand shocks in other counties linked through firms' internal networks. These results are not driven by direct demand spillovers from nearby counties, common shocks to house prices, or local demand shocks affecting non-tradable employment in distant counties indirectly via the trade channel. Our results suggest that firms play an important role in the extent to which local labor market risks are shared across regions.
\end{abstract}

\author{
Xavier Giroud \\ MIT Sloan School of Management \\ 100 Main Street, E62-639 \\ Cambridge, MA 02142 \\ and NBER \\ xgiroud@mit.edu \\ Holger M. Mueller \\ Stern School of Business \\ New York University \\ 44 West Fourth Street \\ Suite 9-190 \\ New York, NY 10012-1126 \\ and NBER \\ hmueller@stern.nyu.edu
}




\section{Introduction}

Incomplete markets and credit constraints make it difficult to fully insure against local labor market shocks. ${ }^{1}$ While labor mobility can mitigate the impacts of local shocks, there is mounting evidence that the movement of labor across regions in the aftermath of shocks is sluggish and, at best, incomplete. ${ }^{2}$ Accordingly, economists have focused on the role of public policy in alleviating the adverse impacts of local shocks, including regional transfers, redistributive taxation, and "place-based" policies that directly target disadvantaged regions: "redistributive countercyclical policies that target localities hit by negative shocks can act as government-provided insurance against housing and labor market risks that are difficult to insure" (Kline and Moretti (2014b, p. 655)). ${ }^{3}$

Using confidential micro data from the U.S. Census Bureau's Longitudinal Business Database (LBD), this paper shows that firms redistribute the adverse impacts of local labor market shocks across regions through their internal networks of establishments. In principle, such a redistribution can be optimal if firms face binding overall resource constraints and individual firm units exhibit decreasing marginal returns. In that case, firms may smooth out local shocks by effectively spreading their impacts across multiple firm units, a manifestation of the well-known "coinsurance effect" (Lewellen (1971)). ${ }^{4}$ As a result, local shocks may induce employment losses at remote establishments.

\footnotetext{
${ }^{1}$ A large regional risk-sharing literature rejects the null of perfect insurance across regions, e.g., Asdrubaldi, Sørensen, and Yosha (1996), Hess and Shin (1998), Del Negro (2002), and Lustig and Van Nieuwerburgh (2010).

${ }^{2}$ See, e.g., Blanchard and Katz (1992), Autor, Dorn, and Hanson (2013, 2016), Autor et al. (2014), and Yagan (2016). Labor mobility may be low either due to high mobility costs or because workers are compensated for declining wages and employment through cost-of-living adjustments (Notowidigo (2013)).

${ }^{3}$ See, e.g., Bartik (1991), Glaeser and Gottlieb (2008), Busso, Gregory, and Kline (2013), Kline and Moretti (2013, 2014a, 2014b), Moretti (2014), and Hurst et al. (2016).

${ }^{4}$ The coinsurance effect is well grounded both in theory and prior empirical work. For instance, in the theory model by Inderst and Mueller (2003), the firm's headquarters smoothes out cash-flow shocks by cross-subsidizing individual firm units with resources from other firm units. Cross-subsidization is optimal because the firm is overall resource constrained and individual firm units exhibit decreasing marginal returns to scale. As for prior empirical work, Lamont (1997) shows that in response to the oil price shock of 1986 - in which oil prices fell by 50 percent - diversified oil companies cut investment not only in their oil extraction segments but also in unrelated segments, such as chemicals, railroads, and shipbuilding. Likewise, Peek and Rosengren (1997, 2000) find that Japanese banks cut their lending activities in the U.S. in response to a domestic liquidity shock in Japan.
} 
We document how firms smooth out the impacts of local labor market shocks by exploiting county-level variation in house prices during the Great Recession. As prior research has shown, the collapse in house prices during the Great Recession caused a sharp drop in consumer demand by households (Mian, Rao, and Sufi (2013), Kaplan, Mitman, and Violante (2016)). This drop in consumer demand, in turn, led to massive employment losses in the non-tradable sector: across U.S. counties, those with larger declines in housing net worth experienced significantly larger declines in non-tradable employment (Mian and Sufi (2014), Giroud and Mueller (2016)).

An important feature of non-tradable employment (e.g., restaurants, supermarkets, retail stores) is that it relies on local consumer demand. This makes it a desirable outcome variable to study the effects of local demand shocks, such as those originating from falling house prices. The same feature also makes it a desirable outcome variable to study redistributive firm policies, albeit for a slightly different reason: while local demand shocks may directly affect non-tradable employment at the local level, they should not directly affect non-tradable employment in distant regions. Hence, if an establishment in the nontradable sector experiences a decline in employment in response to a local demand shock in some other region in which the firm has establishments, then it is unlikely that this employment decline is due to a direct demand effect from that region.

We find that non-tradable establishment-level employment responds strongly to local demand shocks in other counties in which the firm has establishments. In fact, the elasticity of non-tradable establishment-level employment with respect to house prices in other counties is about thirty percent of the elasticity with respect to local house prices in the establishment's own county. ${ }^{5}$ Our main specification includes county fixed effects. Accordingly, we can compare non-tradable establishments in the same county that are exposed to the same local demand shock but that belong to different firms and hence

\footnotetext{
${ }^{5}$ As in Mian, Rao, and Sufi (2013), Mian and Sufi (2014), Stroebel and Vavra (2015), Kaplan, Mitman, and Violante (2016), and Giroud and Mueller (2016), we equate falling house prices during the Great Recession with shocks to local consumer demand. Indeed, Mian, Rao, and Sufi (2013) and Kaplan, Mitman, and Violante (2016) provide direct evidence showing that counties or CBSAs experiencing larger declines in housing net worth exhibit larger declines in consumer spending during the Great Recession. Likewise, Stroebel and Vavra (2015) find that homeowners become more price-sensitive and cut back more on their retail spending in ZIP codes experiencing larger drops in house prices.
} 
are exposed to different demand shocks in other counties. Importantly, the county fixed effects absorb any common shocks at the county level, including those arising in general equilibrium through spillovers from other counties (e.g., price effects).

Consistent with theory, we find that the elasticity of establishment-level employment with respect to house prices in other counties increases with firms' financial constraints. Indeed, with respect to the least financially constrained firms in our sample, we find no evidence that local demand shocks spill over to remote establishments within the same firm. Furthermore, and consistent with the notion that firms smooth out the impacts of local labor market shocks across regions, we find that establishments of firms with more expansive regional networks exhibit significantly lower elasticities with respect to local house prices in the establishment's own county.

Firms' redistributive policies may be irrelevant in general equilibrium if workers laid off due to demand shocks in other counties are re-employed by local firms that are less exposed to these counties. To see whether firms' redistributive policies matter in the aggregate, we examine total non-tradable employment at the county level. Building on our establishment-level analysis, we construct a network of U.S. counties by aggregating county-level linkages across establishments based on firms' internal networks. Similar to what we found at the establishment level, we find that non-tradable county-level employment responds strongly to local demand shocks in other counties linked through firms' internal networks. ${ }^{6}$ Indeed, the elasticity of non-tradable county-level employment with respect to house prices in other counties is about twenty percent of the (local) elasticity with respect to a county's own house prices. While this is a large magnitude, it is somewhat smaller than what we found at the establishment level, possibly reflecting the impacts of general equilibrium adjustments.

Restaurants, supermarkets, and retail stores cater to local consumer demand. The question, however, is: how "local" is consumer demand? Arguably, consumers may go to restaurants and grocery stores across county borders, especially if they live close to the

\footnotetext{
${ }^{6}$ It is important that county-level linkages are based on firms' internal networks. If we assign equal weight to all other counties - or to a randomly selected sample of counties - there is no significant effect. Likewise, there is no significant effect if we randomly assign county-level linkage weights from the population of actual linkage weights or use placebo weights based on tradable firms' internal networks.
} 
border. Hence, one might be worried that our estimates are picking up direct demand effects from other counties. We find that direct demand spillovers are small at best. If we control for proximity-weighted house prices in other counties, our estimates become only slightly weaker, and they remain highly significant. The same is true if we exclude adjacent counties or those within a 50, 100, 150, or 250 mile radius.

Common factors affecting house prices in counties in which non-tradable firms have their establishments may introduce collinearity, making our estimates difficult to interpret. We address this issue in three ways. First, we consider demographic and other factors that constitute potential sources of common shocks (income, education, age, mortgage debt, mortgage delinquencies, household debt). We find that controlling for "similarityweighted" house prices in other counties based on similarities in these factors has little effect on our results. Second, we instrument house prices using the housing supply elasticity instrument from Saiz (2010). Third, we consider a subset of counties in which house prices did not fall during the Great Recession. Linking such counties to other counties in which house prices fell sharply makes it unlikely that our results are driven by common shocks to house prices. Our results always remain similar.

Finally, local demand shocks may indirectly affect non-tradable employment in other counties via the trade channel. Precisely, they may lead to employment losses in other counties in the tradable sector, which in turn may spill over to the non-tradable sector if workers that were laid off cut back on their local grocery shopping and restaurant visits. A necessary condition for this (trade) channel to work is that local house prices affect tradable employment in other counties. As it turns out, however, local house prices have no significant effect on employment in the tradable sector, neither at the local level nor in distant counties.

Our paper contributes to three strands of literature. First and foremost, it is related to the literature mentioned earlier that studies how risk is shared across regions and how public policy can mitigate the adverse impacts of local labor market shocks through redistributive taxation, regional transfers, and "place-based" policies that directly target disadvantaged regions. Our paper adds to this literature by showing that firms play an important role in redistributing the impacts of local labor market shocks across regions 
through their internal networks of establishments.

Second, a recent literature studies cross-sectional variation in house prices during the Great Recession and its implications for consumer demand and non-tradable employment (e.g., Mian, Rao and Sufi (2013), Mian and Sufi (2014), Stroebel and Vavra (2015), Kaplan, Mitman, and Violante, (2016), Giroud and Mueller (2016)). Our paper shows that local consumer demand shocks not only affect local non-tradable employment but also non-tradable employment in distant regions. Indeed, we find economically large elasticities of non-tradable employment with respect to demand shocks in other regions, echoing a point made in Beraja, Hurst, and Ospina (2016) that it is difficult to draw inferences about aggregate economic activity based on local elasticities alone. In our empirical setting, local elasticities and those with respect to demand shocks in other regions have the same sign. Accordingly, including elasticities with respect to demand shocks in other regions strengthens the role of consumer demand in explaining the sharp decline in U.S. employment during the Great Recession.

Third, our paper is related to empirical studies documenting how shocks propagate through networks. Prior research has focused on production (i.e., input-output) networks (Acemoglu, Akcigit, and Kerr (2015), Acemoglu et. al (2016), Barrot and Sauvagnat (2016)), social networks (Bailey et al. (2016)), and banking networks (Peek and Rosengren (1997, 2000), Schnabl (2012)). By contrast, our paper studies how shocks propagate across different regional labor markets within the same (non-tradable) industry sector through firms' internal networks of establishments. An important benefit of using U.S. Census Bureau data is that we can characterize the entire network structure: the Longitudinal Business Database includes the ZIP codes and firm affiliations of all (payroll) establishments in the U.S.

The rest of this paper is organized as follows. Section 2 describes the data, variables, and summary statistics. Section 3 shows how firms redistribute the adverse impacts of local labor market shocks across regions through their internal networks of establishments. Section 4 considers the implications of redistributive firm policies for aggregate non-tradable employment at the county level. Section 5 concludes. 


\section{Data, Variables, and Summary Statistics}

\subsection{Data}

We use data on employment, location, industry affiliation, and firm affiliation at the establishment level. An establishment is a "single physical location where business is conducted" (Jarmin and Miranda (2002, p. 5)), e.g., a restaurant, grocery store, gas station, or department store. The establishment-level data are provided by the U.S. Census Bureau's Longitudinal Business Database (LBD). The LBD covers all business establishments in the U.S. with at least one paid employee.

Our focus is on establishments in the non-tradable industry sector. An important feature of non-tradable employment is that it relies on local consumer demand. Thus, if an establishment experiences a decline in employment in response to a local demand shock in some other region, then it is unlikely that this employment decline is due to a direct demand effect from that region. We classify establishments as non-tradable based on the industry categorization in Mian and Sufi (2014). Accordingly, 26 four-digit NAICS industries are classified as non-tradable. Among those, the largest ones in terms of U.S. employment shares in 2007 are full-service restaurants (3.76\%), limited-service eating places $(3.40 \%)$, grocery stores $(2.13 \%)$, department stores $(1.36 \%)$, other general merchandise stores $(1.12 \%)$, clothing stores $(1.06 \%)$, automobile dealers $(1.05 \%)$, health and personal care stores $(0.89 \%)$, and gasoline stations $(0.73 \%)$.

We match establishments to county-level house prices. Our house price data are from Zillow. $^{7}$ Changes in house prices from 2006 to 2009 based on Zillow data are highly correlated with the "housing net worth shock" in Mian, Rao and Sufi (2013) and Mian and Sufi (2014), $\Delta$ Housing Net Worth, 2006-2009. The correlation at the MSA level is 86.3 percent. Likewise, they are highly correlated with changes in house prices from 2006 to 2009 based on data from the Federal Housing Finance Agency (FHFA). The correlation at the MSA level is 96.4 percent. We have data on house prices for 1,000 counties representing 86.8 percent of total U.S. employment and 85.8 percent of non-

\footnotetext{
${ }^{7}$ Zillow house price data have been used in, e.g., Keys et al. (2014), Mian, Sufi, and Trebbi (2015), Giroud and Mueller (2016), Kaplan, Mitman, and Violante (2016), and Bailey et al. (2016).
} 
tradable employment. ${ }^{8}$

In addition, we use data on population, age, and education from the 2000 Decennial Census, data on adjusted gross income per capita in 2006 from the IRS, and data on mortgage debt, mortgage delinquencies, and household debt (mortgage, auto, and credit card debt), all per capita in 2006, from the FRBNY Consumer Credit Panel. Also, we use measures of housing supply elasticity and "share of unavailable land" from Saiz (2010). Lastly, we compute measures of firms' financial constraints - firm leverage and the financial constraints indices of Kaplan and Zingales (1997) and Whited and Wu (2006), all in 2006 - using information from Compustat. We match establishments in the LBD to firms in Compustat using the Compustat-SSEL bridge maintained by the U.S. Census Bureau. As this bridge ends in 2005, we extend the match to 2009 using employer name and ID number (EIN) following the procedure described in McCue (2003).

\subsection{Variables and Empirical Specification}

We examine how firms redistribute the impacts of local consumer demand shocks by exploiting county-level variation in house prices during the Great Recession. As prior research has shown, the massive decline in house prices during the Great Recession caused a sharp drop in consumer demand by households. This drop in consumer demand, in turn, led to substantial employment losses in the non-tradable sector: across U.S. counties, those with larger declines in housing net worth experienced significantly larger declines in nontradable employment. Given that we wish to examine how firms redistribute the adverse employment impacts of local consumer demand shocks across regions, our establishmentlevel analysis focuses on firms operating in multiple counties. As our house price data are at the county level, we aggregate across all establishments of a firm within a given county. Accordingly, the unit of observation is at the firm-county level. In robustness tests, we alternatively aggregate at the firm-county-industry level. For simplicity, we refer to individual units as "establishments."

\footnotetext{
${ }^{8}$ All sample sizes in this paper are rounded to the nearest hundred following disclosure guidelines by the U.S. Census Bureau.
} 
We estimate the following equation:

$$
\Delta \log \left(\operatorname{Emp}_{h, i}\right)_{07-09}=\alpha+\eta_{1} \Delta \log \left(\mathrm{HP}_{i}\right)_{06-09}+\eta_{2} \sum_{j \neq i} \omega_{h, i, j} \Delta \log \left(\mathrm{HP}_{j}\right)_{06-09}+\varepsilon_{h, i}
$$

where $\Delta \log \left(\operatorname{Emp}_{h, i}\right)_{07-09}$ is the percentage change in employment from 2007 to 2009 at establishments of firm $h$ in county $i, \Delta \log \left(\mathrm{HP}_{i}\right)_{06-09}$ is the percentage change in house prices from 2006 to 2009 in county $i$, and $\sum_{j \neq i} \omega_{h, i, j} \Delta \log \left(\mathrm{HP}_{j}\right)_{06-09}$ is the linkageweighted percentage change in house prices from 2006 to 2009 in counties $j \neq i$. For brevity, we write $\Delta \log (\mathrm{HP})_{06-09}$ (other) in lieu of $\sum_{j \neq i} \omega_{h, i, j} \Delta \log \left(\mathrm{HP}_{j}\right)_{06-09}$ in our figures and tables. The (partial) elasticities of interest are $\eta_{1}$ and, especially, $\eta_{2}$. All regressions are weighted by establishment (i.e., firm-county) employment and include either county fixed effects or the county-specific employment shares of all 23 two-digit NAICS industries in 2006 as controls. Some regressions include county $\times$ industry fixed effects in place of county fixed effects. Naturally, in the regressions that include either county or county $\times$ industry fixed effects, the percentage change in county-level house prices, $\Delta \log \left(\mathrm{HP}_{i}\right)_{06-09}$, is absorbed by the fixed effects. Standard errors are double clustered at both the firm and county level.

Our regression specification provides us with (partial) elasticities of non-tradable establishment-level employment with respect to local house prices in the establishment's own county $\left(\eta_{1}\right)$ as well as other counties in which the firm has establishments $\left(\eta_{2}\right)$. The variant of our specification that includes fixed effects is equivalent to a differencein-differences specification with either county $\times$ year or county $\times$ industry $\times$ year fixed effects and one "before" and one "after" period. Accordingly, identification comes from saturating the model with highly granular fixed effects. Importantly, these fixed effects account for any common shocks at the county level, including those arising in general equilibrium through spillovers from other counties (e.g., price effects).

The linkage weights $\omega_{h, i, j}$ specify the relative weight of house prices in county $j$ for establishments of firm $h$ in county $i$. We impose the minimal assumption that linkage weights be proportional to firms' (non-tradable) employment in a county: 


$$
\omega_{h, i, j}=\frac{\operatorname{Emp}_{h, j}}{\sum_{k \neq i} \operatorname{Emp}_{h, k}} .
$$

Hence, a local demand shock in county $j$ matters more for an establishment of firm $h$ in county $i$ if the firm is more exposed to county $j$ as measured by its employment in county $j$ relative to other counties $k \neq i .^{9}$ Simply put, an establishment is more exposed to a given county if its firm is more exposed to that county. Naturally, a county's weight is zero if the firm has no employees in that county.

If firms redistribute the adverse employment impacts of local demand shocks across regions, we would expect that $\eta_{2}>0$. The null is that firms do not reallocate internal resources in response to local shocks, i.e., $\eta_{2}=0 .{ }^{10}$ Finally, there is a third possibility, namely, $\eta_{2}<0$. Under this possibility, firms do not cross-subsidize units in adversely affected regions but, quite the contrary, reallocate resources away from such units and toward units in less affected regions. ${ }^{11}$

In the second part of this paper, we consider aggregate employment at the county level to examine if firms' redistributive policies matter in general equilibrium. Countylevel employment is total non-tradable employment by all firms in a county. Thus, we no longer focus exclusively on multi-county firms. This accounts for the possibility that workers laid off due to demand shocks in other counties are re-employed either by other multi-county firms or by local single-county firms.

Analogous to above, we estimate the following equation:

$$
\Delta \log \left(\operatorname{Emp}_{i}\right)_{07-09}=\alpha+\eta_{1} \Delta \log \left(\mathrm{HP}_{i}\right)_{06-09}+\eta_{2} \sum_{j \neq i} \lambda_{i, j} \Delta \log \left(\mathrm{HP}_{j}\right)_{06-09}+\varepsilon_{i}
$$

where $\Delta \log \left(\operatorname{Emp}_{i}\right)_{07-09}$ is the percentage change in non-tradable employment from 2007

\footnotetext{
${ }^{9}$ Bailey et al. (2016) use analogous county-level linkage weights in the context of social networks.

${ }^{10}$ Alternatively, $\eta_{2}=0$ could imply that firms do not face binding resource constraints.

${ }^{11}$ This third possibility is consistent with a view whereby drops in consumer spending during the Great Recession reflect long-term changes in consumer preferences rather than cyclical shocks to households' budget constraints due to falling house prices (and/or household deleveraging). See Stein (1997) for a theory model in which the firms' headquarters reallocates internal resources toward firm units whose relative investment opportunities have increased and Stein (2003) for a comprehensive overview of the literature on internal resource allocation within firms.
} 
to 2009 in county $i, \Delta \log \left(\mathrm{HP}_{i}\right)_{06-09}$ is the percentage change in house prices from 2006 to 2009 in county $i$, and $\sum_{j \neq i} \lambda_{i, j} \Delta \log \left(\mathrm{HP}_{j}\right)_{06-09}$ is the linkage-weighted percentage change in house prices from 2006 to 2009 in counties $j \neq i$. Like above, we write $\Delta$ $\log (\mathrm{HP})_{06-09}$ (other) instead of $\sum_{j \neq i} \lambda_{i, j} \Delta \log \left(\mathrm{HP}_{j}\right)_{06-09}$ in our figures and tables for brevity. All regressions are weighted by county size (number of employees) and includethe county-specific employment shares of all 23 two-digit NAICS industries in 2006 as controls. Standard errors are clustered at the state level.

The linkage weights $\lambda_{i, j}$ specify the relative weight of house prices in county $j$ for nontradable employment in county $i$. They are obtained by taking the employment-weighted average of individual establishment-level linkage weights $\omega_{h, i, j}$ within a county:

$$
\lambda_{i, j}=\sum_{h} \frac{\operatorname{Emp}_{h, i}}{\sum_{k} \operatorname{Emp}_{k, i}} \omega_{h, i, j},
$$

where $\sum_{h}\left(\operatorname{Emp}_{h, i} / \sum_{k} \operatorname{Emp}_{k, i}\right)=1$. Hence, a local demand shock in county $j$ matters more for county $i$ if its establishments are more exposed to county $j$ (high $\omega_{h, i, j}$ ) and these establishments have relatively high employment shares within county $i$.

\subsection{Summary Statistics}

Table I provides basic summary statistics. In the top part of Panel (A), the sample is restricted to multi-county firms and the unit of observation is at the firm-county level, consistent with our empirical analysis in Section 3. As can be seen, non-tradable firmcounty units have on average 75.9 employees and are linked to 192.5 other counties through their firms' internal networks of establishments. ${ }^{12}$ During the Great Recession, nontradable firm-county units experienced a decline in employment of 2.9 percent, while house prices at the county level fell by 14.5 percent. ${ }^{13}$

The bottom part of Panel (A) provides county-level summary statistics based on all

\footnotetext{
${ }^{12}$ Based on 2006 figures. Firm-county units are obtained by aggregating across all establishments of a firm within a given county. Individual establishments have 29.5 employees on average, implying that a typical firm-county unit consists of 2.5 establishments.

${ }^{13}$ All percentages in Table I are weighted by either firm-county or county-level employment in 2006.
} 
non-tradable firms in a county - including single-county firms - consistent with the empirical analysis in Section 4. As is shown, the average county has 1,074 establishments and 18,490 employees in the non-tradable sector, accounting for 18.6 percent of total county-level employment. During the Great Recession, aggregate non-tradable countylevel employment fell by 3.6 percent, which is slightly higher than the figure reported above for multi-county firms.

Linkages across counties based on firms' internal networks are pervasive. If we impose the minimal requirement that linkages be based on $10+$ employees, almost all counties are connected with each other ("Starbucks effect"). If we impose the requirement that linkages be based on 1,000+ employees, the average county is connected to about half of the other counties. This is a sizable network, reflecting the prominent role of national restaurant and retail chains in the non-tradable sector. That most counties are connected with each other is not a concern. Variation in $\Delta \log (\mathrm{HP})_{06-09}$ (other) comes primarily from variation in the linkage weights, not variation in the number of connections. Indeed, Figures I and II show that there is substantial variation in $\Delta \log (\mathrm{HP})_{06-09}$ (other).

Panel (B) of Table I reports correlations between county-level linkages based on firms' internal networks of establishments and either county or county-pair characteristics. The first two correlations show that non-tradable firms have more employees in nearby and more populous counties. Both correlations are intuitive. The first reflects the fact that some non-tradable firms are regional firms. The second correlation reflects the fact that national restaurant and retail chains have more employees in regions with more potential customers. The remaining correlations document that, on average, non-tradable firms operating in a given county do not have more employees in "similar" counties based on similarities in either income, age, education, mortgage debt, mortgage delinquencies, household debt, or changes in house prices in the Great Recession. While individual nontradable firms may well choose the locations of their establishments based on demographic factors - e.g., dollar stores may primarily target low-income areas - our sample includes a large number of non-tradable firms, with potentially diverse target audiences, implying that similarities across counties based on individual firms' target audiences "wash out" in the aggregate. 


\section{Spatial Redistribution of Local Demand Shocks}

This section attempts to shed light on the mechanism underlying the redistribution of local demand shocks across regions. To do so, we look inside the firm and examine how non-tradable employment at the establishment level responds to local demand shocks as well as demand shocks in other regions in which the firm has establishments. Section 4 below examines the aggregate implications of redistributive firm policies.

\subsection{Redistribution through Firms' Internal Networks}

Figure I provides a visual impression by plotting the relationship between changes in nontradable establishment-level employment during the Great Recession and either changes in county-level house prices (top panel) or changes in house prices in other counties in which the firm has establishments (bottom panel). To filter out any confounding effects of $\Delta \log (\mathrm{HP})_{06-09}$ (other) when plotting the relationship between $\Delta \log (\operatorname{Emp})_{07-09}$ and $\Delta \log (\mathrm{HP})_{06-09}$, we compute the residuals from a regression of $\Delta \log (\operatorname{Emp})_{07-09}$ on a constant and $\Delta \log (\mathrm{HP})_{06-09}$ (other). These residuals represent the component of $\Delta$ $\log (\operatorname{Emp})_{07-09}$ that is orthogonal to, and thus unexplained by, $\Delta \log (\mathrm{HP})_{06-09}$ (other). For each percentile of $\Delta \log (\mathrm{HP})_{06-09}$, the plot shows the mean values of the residuals and $\Delta \log (\mathrm{HP})_{06-09}$, respectively. We proceed analogously in the bottom panel when plotting the relationship between $\Delta \log (\operatorname{Emp})_{07-09}$ and $\Delta \log (\mathrm{HP})_{06-09}$ (other).

The top panel shows that there is a positive association between changes in nontradable employment at the establishment level and changes in (local) county-level house prices, consistent with prior literature. The elasticity with respect to local house prices is 0.117, meaning a ten percent decline in local house prices is associated with a 1.17 percent decline in establishment-level employment. (The average decline in county-level house

prices between 2006 and 2009 is 14.5 percent.) The bottom panel depicts the relationship between changes in non-tradable employment at the establishment level and house prices in other counties in which the firm has establishments. As is shown, the elasticity with respect to house prices in other counties is 0.031 , which is almost thirty percent of the elasticity with respect to local house prices. This is a large magnitude, suggesting that 
employment at the establishment level is highly sensitive to demand shocks in other counties in which the firm has establishments.

Table II confirms this visual impression using regression analysis. Columns (1) and (2) include the county-specific employment shares of all 23 two-digit NAICS industries in 2006 as controls to account for the possibility that counties with exposure to certain industries are harder hit during the Great Recession (Mian and Sufi (2014)). As column (1) shows, local demand shocks have a profound effect on non-tradable employment at the establishment level. The elasticity with respect to local house prices is 0.104 , implying that a ten percent decline in local house prices is associated with a 1.04 percent decline in establishment-level employment.

Column (2) includes the effect of changes in house prices in other counties in which the firm has establishments. While the coefficient associated with changes in local house prices, $\Delta \log (\mathrm{HP})_{06-09}$, drops slightly to 0.092 , that associated with changes in house prices in other counties, $\Delta \log (\mathrm{HP})_{06-09}$ (other), is large and significant. Indeed, the elasticity with respect to house prices in other counties is 0.029 , which is more than thirty percent of the elasticity with respect to local house prices.

In column (3), we replace our county-specific industry controls with county fixed effects. Accordingly, we can compare non-tradable establishments in the same county that are exposed to the same local demand shock but that belong to different firms and hence are exposed to different demand shocks in other counties. More generally, the county fixed effects account for any common shocks at the county level, including those arising in general equilibrium through spillovers from other counties (e.g., price effects). As can be seen, the elasticity with respect to house prices in other counties is almost identical to that in column (2).

Columns (4) to (6) provide robustness tests in which we aggregate establishments at the firm-county-industry level instead of the firm-county-level. In principle, doing so allows for tighter identification, as we can compare non-tradable establishments in the same county and 4-digit NAICS industry as opposed to the same county. As it turns out, however, this has virtually no effect on our estimates. In particular, the elasticity with respect to house prices in other counties in column (6), which includes county $\times$ industry 
fixed effects, is practically identical to that in column (3), which includes county fixed effects (0.028 versus 0.027$)$. In the remainder of this section, we therefore use column (3) as our main specification. Presumably, the reason why it makes little difference whether we aggregate at the firm-county or firm-county-industry level is that all establishments in our sample belong to the non-tradable industry sector, which is already a relatively homogeneous group of industries. Perhaps more important, $89.9 \%$ of the firms in our sample have all of their non-tradable establishments in a single 4-digit NAICS industry. For these firms, it makes literally no difference whether we aggregate at the firm-county or firm-county-industry level.

Overall, our results are consistent with firms smoothing out the adverse employment impacts of local demand shocks across different regions. However, while our results are consistent with (co-)insurance, they are not consistent with full insurance: elasticities with respect to "own" demand shocks are several times larger than those with respect to demand shocks in other regions. One possible explanation is that firms associate, at least to some extent, drops in consumer spending in hard-hit regions with permanent declines in investment opportunities in these regions. Another explanation is that agency problems and frictions inside the firm (e.g., lobbying) impair the efficient redistribution of resources across establishments. Lastly, it may simply be easier to justify laying off workers in regions that are harder hit during the Great Recession.

\subsection{Financial Constraints}

Theory predicts that the extent to which firms reallocate internal resources in response to shocks depends on their financial constraints, given that it is costly to withdraw resources from other firm units that are positive NPV at the margin. In Table III, we take this prediction to the data using different measures of firms' financial constraints: firm leverage, the Kaplan-Zingales index (Kaplan and Zingales (1997)), and the Whited-Wu index (Whited and $\mathrm{Wu}(2006)$ ), all measured in 2006. The first measure is based on Giroud and Mueller (2016), who argue that firms with higher leverage in 2006, at the onset of the Great Recession, were more financially constrained during the Great Recession. The 
second and third measures are widely used in the finance literature. All three measures are only available for public firms. Accordingly, we restrict our sample to firms that have a match in Compustat.

Regardless of which measure of financial constraints (FC) we use, we find that the interaction term $\Delta \log (\mathrm{HP})_{06-09}$ (other) $\times \mathrm{FC}$ is positive and significant. Thus, establishments of more financially constrained firms exhibit significantly larger elasticities of employment with respect to house prices in other counties in which the firm has establishments. Indeed, with regard to the least financially constrained firms in our sample, we find no evidence that these firms redistribute the employment impacts of local demand shocks across their establishments. Finally, and consistent with prior literature, we find that establishments of more financially constrained firms exhibit larger elasticities with respect to local house prices in the establishment's own county. Altogether, these results suggest that financial constraints matter, both for how firms respond locally to labor market shocks and for how they smooth out the impacts of these shocks across regions.

\subsection{Scope of Firms' Regional Networks}

If firms smooth out the impacts of local labor market shocks across regions, then establishments of firms with more expansive regional networks should respond less strongly to local labor market shocks in the establishment's own county. We test this prediction in Table IV using different proxies for the scope of firms' regional networks: a dummy indicating whether a firm is a multi-county firm, the number of counties in which the firm has non-tradable employment, and a firm-level Herfindahl-Hirschman Index (HHI) measuring the extent of the firm's geographic concentration based on its non-tradable employment at the county level. (We use one minus the HHI to allow all three proxies to have the same economic interpretation.) The first proxy requires that we expand our sample to all non-tradable firms within a county, including single-county firms. As for the second and third proxy, we use our original sample of multi-county firms to avoid picking up differences between single- and multi-county firms, given that these differences have already been captured by our multi-county dummy. 
Irrespective of how we measure the scope of firms' regional networks $(\mathrm{RN})$, we find that the interaction term $\Delta \log (\mathrm{HP})_{06-09} \times \mathrm{RN}$ is negative and significant. Accordingly, establishments of firms with more expansive regional networks exhibit significantly smaller elasticities of employment with respect to local house prices. Given that firms with larger regional networks may also differ along other dimensions, we view the evidence provided in Table IV as suggestive. In particular, firms with larger regional networks may be larger in general. For instance, our sample includes restaurant, supermarket, and department store chains; these are often both large and widely spread across regions. In columns (4) to (6), we therefore include as additional controls firm size (number of employees) in 2006 as well as its interaction with $\Delta \log (\mathrm{HP})_{06-09}$. While this reduces the effect of regional networks somewhat, the latter remains large and significant. Hence, accounting for differences in firm size, establishments belonging to firms with larger regional networks respond less strongly to local demand shocks in the establishment's own county.

\section{Aggregate Employment at the County Level}

Firms' redistributive policies may be irrelevant in general equilibrium if workers laid off due to demand shocks in other counties are re-employed by firms that are less exposed to these counties. In principle, such general equilibrium adjustments may be impaired by wage and price stickiness as well as imperfect substitutability in the goods market. In addition, the extent of labor reallocation depends on search and matching frictions in the labor market as well as labor adjustment costs. Empirical evidence suggests that labor market frictions were particularly severe during the Great Recession (e.g., Davis, Faberman, and Haltiwanger (2013), Şahin et al. (2014)). Notably, Foster, Grim, and Haltiwanger (2014) document that the intensity of labor reallocation fell rather than rose during the Great Recession, in stark contrast to previous recessions. The authors conclude: "job reallocation (creation plus destruction) is at its lowest point in 30 years during the Great Recession and its immediate aftermath" (p. 10).

To examine whether firms' redistributive policies matter in the aggregate, we turn to county-level regressions. We consider total non-tradable employment by all firms in 
a county, including single-county firms. Hence, our setting accounts for the possibility that workers laid off due to demand shocks in other counties are re-employed either by other multi-county firms or by local single-county firms. Linkages across counties are based on individual firms' internal networks of establishments as described in Section 2.2. All regressions include the county-specific employment shares of all 23 two-digit NAICS industries in 2006 as controls to account for the possibility that counties with exposure to certain industries are harder hit during the Great Recession.

\subsection{Main County-Level Results}

Figure II plots the relationship between changes in non-tradable county-level employment during the Great Recession and either changes in county-level house prices (top panel) or changes in house prices in other counties linked through firms' internal networks of establishments (bottom panel). The figure is constructed the same way as Figure I. As can be seen, both plots are similar to those in our establishment-level analysis. In the top panel, there is a positive association between changes in non-tradable countylevel employment and changes in county-level house prices, confirming similar results in prior literature. The elasticity with respect to county-level house prices is 0.129 . This is slightly larger than in our establishment-level analysis, reflecting the fact that countylevel employment is based on all firms in a county, including single-county firms. In the bottom panel, the elasticity with respect to house prices in other counties is 0.030 , suggesting that county-level employment is highly sensitive to local demand shocks in other counties linked through firms' internal networks. Indeed, the elasticity with respect to house prices in other counties is more than twenty percent of the elasticity with respect to a county's own house prices. While this is a large magnitude, it is somewhat smaller than what we previously found at the establishment level, possibly reflecting the impacts of general equilibrium adjustments.

Table V confirms this visual impression using regression analysis. In column (1), the elasticity of non-tradable county-level employment with respect to county-level house prices is 0.122 , which is only slightly lower than in our graphical analysis. Column (2), 
which is our main specification, includes the effect of changes in house prices in other counties linked through firms' internal networks. While the coefficient associated with a county's own change in house prices, $\Delta \log (\mathrm{HP})_{06-09}$, drops slightly to 0.115 , the coefficient associated with changes in house prices in other counties, $\Delta \log (\mathrm{HP})_{06-09}$ (other), is large and significant. Indeed, the elasticity of non-tradable employment with respect to house prices in other counties is 0.024 , which is about twenty percent of the elasticity with respect to a county's own house prices.

A quick back-of-the-envelope calculation suggests that consumer demand shocks can explain a significant portion of the drop in non-tradable employment during the Great Recession. As the summary statistics in Table I show, non-tradable employment at the county level dropped by 3.6 percent, while county-level house prices fell by 14.5 percent. Given the elasticities of 0.115 and 0.024 in column (2), a drop in house prices of 14.5 percent therefore implies a drop in non-tradable employment of $(0.115+0.024) \times 14.5 \%=$ $1.95 \%$, amounting to more than half of the overall decline in non-tradable employment. Notably, more than twenty percent of the decline in non-tradable employment explained by consumer demand shocks $(0.024 / 0.115=0.209)$ is due to shocks originating in other counties linked through firms' internal networks.

What is important for our results is that county-level linkages are based on firms' internal networks of establishments. In column (3), we construct counterfactual linkages by assigning equal weight to all other counties. As can be seen, there is no significant spillover effect. Similarly, in column (4), we assign equal weight to a randomly selected sample of counties. Precisely, we draw for each county a random sample of 1,000 counties (with replacement) and compute $\Delta \log (\mathrm{HP})_{06-09}$ (other) using equal weights. We repeat this process 1,000 times and estimate our baseline specification for each of the 1,000 bootstrap samples. As can be seen, there is again no significant spillover effect. In column (5), we randomly assign linkage weights from the population of actual linkage weights based on firms' internal networks. That is, for each county, we take its actual set of 1,000 linkage weights but assign them randomly (with replacement). We repeat this process 1,000 times and estimate our baseline specification for each of the 1,000 bootstrap samples. Again, there is no significant spillover effect. Finally, in column 
(6), we use placebo weights based on tradable firms' internal networks. ${ }^{14}$ That is, we construct linkage weights the same way as before, except we use tradable firms in lieu of non-tradable firms. As in the other placebo tests, there is no significant spillover effect.

\subsection{Direct Demand Spillovers}

How "local" is consumer demand? Arguably, consumers may go to restaurants and grocery stores in neighboring counties, especially if they live close to the county border. Hence, one might be worried that our estimates of spillovers from other counties are picking up direct demand effects from these counties. That is, falling house prices in county $j$ may affect non-tradable employment in county $i$ not through firms' internal networks of establishments but rather because consumers in county $j$ cut back on their restaurant visits and grocery shopping in county $i$.

Table VI explores whether our results are driven by direct demand spillovers from nearby counties. In column (1), we directly control for proximity-weighted changes in house prices in other counties. While the coefficient associated with this control is marginally significant, the coefficient associated with $\Delta \log (\mathrm{HP})_{06-09}$ (other) drops only slightly, and it remains highly significant. Hence, direct demand spillovers from nearby counties have a small effect at best. In column (2), we exclude adjacent counties when computing $\Delta \log (\mathrm{HP})_{06-09}$ (other). This rules out any direct demand spillovers from these counties by construction. As can be seen, the coefficient on $\Delta \log (\mathrm{HP})_{06-09}$ (other) is practically identical to that in column (1), and it remains highly significant. Finally, in columns (3) to (6), we exclude all counties within a 50, 100, 150, or 250 mile radius based on the counties' geographical centroids. As is shown, our results always remain similar.

\subsection{Common County-Level Shocks}

Common factors affecting house prices in counties in which non-tradable firms have their establishments may introduce collinearity, making our estimates difficult to interpret. We

\footnotetext{
${ }^{14}$ An industry is classified as as tradable if imports plus exports exceed $\$ 10,000$ per worker or $\$ 500 \mathrm{M}$ in total (Mian and Sufi (2014)). Tradable industries are essentially manufacturing industries.
} 
address this issue in three ways. First, we directly control for changes in house prices in other counties based on similarities in demographic and other factors. Second, we instrument changes in house prices during the Great Recession using the housing supply elasticity instrument from Saiz (2010). Third, we consider a subset of counties in which house prices did not fall during the Great Recession.

\section{Demographic Factors, Household Debt, and House Prices}

Non-tradable firms may choose the locations of their establishments based on specific demographic factors. For instance, dollar stores may primarily target low-income areas, while high-end luxury retailers may primarily target affluent areas. That being said, the summary statistics in Table I show that there is no significant correlation between county-level linkages based on firms' internal networks and county-level linkages based on similarities in either income, education, or age. As we argued previously, our sample includes a large number of non-tradable firms, with potentially diverse target audiences, implying that similarities across counties based on individual firms' target audiences "wash out" in the aggregate.

In columns (1) to (3) of Table VII, we control for "similarity-weighted" changes in house prices in other counties based on similarities in either income, education, or age. Similarity weights place higher weight on counties that are more similar (i.e., smaller absolute difference) to the given county with respect to a particular characteristic. As can be seen, including these controls makes little difference, consistent with there being no significant correlation between linkages based on firms' internal networks and those based on similarities in demographic factors. Importantly, these results do not say that demographics do not matter for house prices. All they say is that the effect of changes in house prices in county $j$ on non-tradable employment in some other county $i$ does not depend on common demographic factors.

Mian and Sufi (2011, 2014), Mian, Rao, and Sufi (2013), and Baker (2015) emphasize the role of household debt during the Great Recession. In columns (4) to (6), we control for similarity-weighted changes in house prices in other counties based on similarities in either mortgage debt, mortgage delinquencies, or household debt (mortgage, auto, and 
credit card debt). As previously, including these controls makes no difference. And again, we would like to caution that this does not mean that mortgage or household debt does not matter for house prices. Rather, it means the effect of changes in house prices in county $j$ on non-tradable employment in county $i$ is unrelated to similarities in either mortgage or household debt among both counties.

If there are common shocks affecting house prices in multiple counties, then house prices should behave similarly in these counties. Accordingly, we can test the "commonshock hypothesis" more directly by controlling for similarity-weighted changes in other counties' house prices based on similarities in $\Delta \log (\mathrm{HP})_{06-09}$. As column (7) shows, including this control makes little difference, implying that our results are not driven by counties experiencing similar changes in house prices during the Great Recession.

\section{Instrumenting House Price Changes}

In Table VIII, we instrument changes in house prices during the Great Recession using the housing supply elasticity instrument from Saiz (2010). This instrument captures geographical and regulatory constraints to new construction. Accordingly, areas with inelastic housing supply face supply constraints due to their topography (steep hills and water bodies) as well as local regulations. The Saiz instrument has been widely used in the literature as a source of exogenous variation in house price changes (e.g., Mian and Sufi (2011, 2014), Mian, Rao, and Sufi (2013), Baker (2015), Stroebel and Vavra (2015), Kaplan, Mitman, and Violante (2016), Giroud and Mueller (2016)). In our specific context, the identifying assumption is that housing supply elasticity in counties $j \neq i$ affects changes in non-tradable employment in county $i$ only through its effect on changes in house prices in counties $j \neq i$.

Columns (1) and (2) show the first-stage regressions. Similar to many other empirical studies, we find that housing supply elasticity is a strong predictor of changes in house prices during the Great Recession. Precisely, a county's own housing supply elasticity is correlated with $\Delta \log (\mathrm{HP})_{06-09}$ but not with $\Delta \log (\mathrm{HP})_{06-09}$ (other), while other counties' housing supply elasticity is correlated with $\log (\mathrm{HP})_{06-09}$ (other) but not with $\Delta \log (\mathrm{HP})_{06-09}$. Importantly, the second-stage regression in column (3) confirms that 
(instrumented) changes in house prices in other counties linked through firms' internal networks have a positive and significant effect on non-tradable employment at the county level. Indeed, the IV elasticities are virtually identical to the OLS elasticities in our baseline specification in column (2) of Table V.

A possible concern with the housing supply elasticity instrument is that it includes regulatory constraints, which may be driven by the same unobserved heterogeneity that also drives employment dynamics. To mitigate this concern, we repeat the analysis in columns (4) to (6) using only the part of the instrument that is based on an area's topology, "share of unavailable land." All results remain similar.

\section{Counties in Which House Prices Did Not Fall}

Not all counties experienced a collapse in house prices during the Great Recession. We exploit this fact in Table IX by focusing on counties in which house prices either increased or changed only little, defined as changes of less than \pm 2.5 percent. Linking such counties to other counties in which house prices fell sharply makes it unlikely that our results are driven by common shocks to house prices.

Columns (1) and (2) focus on counties in which house prices increased during the Great Recession. In column (1), the coefficient associated with $\Delta \log (\mathrm{HP})_{06-09}$ is positive but not significant, presumably because increases in house prices were relatively small during the Great Recession. In column (2), the coefficient associated with $\Delta \log (\mathrm{HP})_{06-09}$ (other) remains large and significant, and its point estimate is similar to that in prior regressions. Thus, local demand shocks in other counties linked through firms' internal networks spill over to counties which experienced no local demand shocks of their own. Columns (3) and (4) focus on counties in which house prices changed only little during the Great Recession. As can be seen, all results are similar.

\subsection{Trade Channel}

We found no evidence that our results may be driven by direct demand spillovers from nearby counties. However, local demand shocks may also indirectly affect non-tradable 
employment in other counties, namely, through the trade channel. Intuitively, falling house prices in county $j$ may lead to employment losses in county $i$ 's tradable sector, which may spill over to county $i$ 's non-tradable sector if workers that were laid off cut back on their local grocery shopping and restaurant visits.

We approach the trade channel hypothesis in two different ways. We first test a necessary condition for this channel to work: if our results are explained by the trade channel, then local house prices should affect tradable employment in other counties. Figure III, which is constructed the same way as Figures I and II, provides a visual impression. As can be seen, there is no clear association between changes in tradable county-level employment and either changes in local house prices (top panel) or changes in house prices in other counties (bottom panel). Column (1) of Table X confirms this visual impression using regression analysis. As in our graphical analysis, we find that neither local house prices nor house prices in other counties have a significant effect on tradable employment at the county level.

The second approach considers county-level employment in the non-tradable sector. Under the trade channel hypothesis, larger (i.e., more populous) counties should have a disproportionate effect on tradable employment in other counties. Hence, if our countylevel linkages were primarily capturing the effects of demand shocks in larger counties,

then this could raise concerns that our estimates might be picking up (indirect) demand effects from these counties via the trade channel. In column (2), we directly control for population-weighted changes in house prices in other counties. Not only is this control insignificant, but the coefficient associated with $\Delta \log (\mathrm{HP})_{06-09}$ (other) remains significant and almost identical to that in our baseline specification. Altoghether, these results suggest that our results are unlikely to be explained by the trade channel.

\section{Conclusion}

Local labor market shocks are difficult to insure against. Accordingly, economists have focused on the role of public policy in mitigating the adverse impacts of local shocks, including regional transfers, redistributive taxation, and "place-based" policies. Using 
confidential micro data from the U.S. Census Bureau's Longitudinal Business Database, we document that firms redistribute the employment impacts of local demand shocks across regions through their internal networks of establishments. At the establishment level, we find that non-tradable employment responds strongly to local demand shocks in other counties in which the firm has establishments. Indeed, the elasticity with respect to house prices in other counties is about thirty percent of the elasticity with respect to local house prices in the establishment's own county. Further, and consistent with the notion that firms smooth out the impacts of labor market shocks across regions, we find that establishments belonging to firms with more expansive regional networks exhibit lower elasticities with respect to house prices in the establishment's own county.

Firms' redistributive policies may be irrelevant in general equilibrium if workers laid off due to demand shocks in other counties are re-employed by local firms that are less exposed to these counties. To examine whether firms redistributive policies matter in the aggregate, we consider total non-tradable employment at the county level. Similar to what we found at the establishment level, we find that non-tradable county-level employment responds strongly to local demand shocks in other counties linked through firms' internal networks of establishments. Indeed, the elasticity with respect to house prices in other counties is about twenty percent of the elasticity with respect to a county's own house prices. This is slightly smaller than what we found at the establishment level, possibly reflecting the impacts of general equilibrium adjustments.

What is crucial for our empirical results is that linkages across counties are based on firms' internal networks of establishments. If we assign equal weight to all other counties - or to a randomly selected sample of counties - there is no significant spillover effect. Likewise, there is no significant spillover effect if we randomly assign linkage weights from the population of actual linkage weights or use placebo weights based on tradable firms' internal networks. Our results are also not driven by direct demand spillovers from nearby counties, common county-level shocks to house prices, or local demand shocks affecting non-tradable employment in distant counties indirectly through the trade channel. Overall, our results suggest that firms play an important role in the extent to which local labor market risks are shared across regions. 


\section{References}

Acemoglu, Daron, Ufuk Akcigit, and William Kerr, 2015, Networks and the Macroeconomy: An Empirical Exploration, forthcoming, NBER Macroeconomics Annual.

Acemoglu, Daron, David Autor, David Dorn, Gordon Hanson, and Brendan Price, 2016, Import Competition and the Great US Employment Sag of the 2000s, Journal of Labor Economics 34, S141-S198.

Asdrubali, Pierfederico, Bent Sørensen, and Oved Yosha, 1996, Channels of Interstate Risk Sharing: United States 1963-1990, Quarterly Journal of Economics 111, 10811110.

Autor, David, David Dorn, and Gordon Hanson, 2013, The China Syndrome: Local Labor Market Effects of Import Competition in the United States, American Economic Review 103, 2121-2168.

Autor, David, David Dorn, and Gordon Hanson, 2016, The China Shock: Learning from Labor Market Adjustment to Large Changes in Trade, forthcoming, Annual Review of Economics.

Autor, David, David Dorn, Gordon Hanson, and Jae Song, 2014, Trade Adjustment: Worker Level Evidence, Quarterly Journal of Economics 129, 1799-1860.

Bailey, Mike, Ruiqing Cao, Theresa Kuchler, and Johannes Stroebel, 2016, Social Networks and Housing Markets, mimeo, New York University.

Baker, Scott, 2015, Debt and the Consumption Response to Household Income Shocks, mimeo, Northwestern University.

Barrot, Jean-Noël, and Julien Sauvagnat, 2016, Input Specificity and the Propagation of Idiosyncratic Shocks in Production Networks, forthcoming, Quarterly Journal of Economics.

Bartik, Timothy, 1991, Who Benefits from State and Local Economic Development Policies? Kalamazoo: W.E. Upjohn Institute.

Beraja, Martin, Erik Hurst, and Juan Ospina, 2016, The Aggregate Implications of Regional Business Cycles, mimeo, University of Chicago. 
Blanchard, Olivier, and Lawrence Katz, 1992, Regional Evolutions, Brookings Papers on Economic Activity, 1-75.

Busso, Matias, Jesse Gregory, and Patrick Kline, 2013, Assessing the Incidence and Efficiency of a Prominent Place Based Policy, American Economic Review 103, 897947.

Davis, Steven, Jason Faberman, and John Haltiwanger, 2013, The Establishment-Level Behavior of Vacancies and Hiring, Quarterly Journal of Economics 128, 581-622.

Del Negro, Marco, 2002, Asymmetric Shocks among U.S. States, Journal of International Economics 56, 273-297.

Foster, Lucia, Cheryl Grim, and John Haltiwanger, 2014, Reallocation in the Great Recession: Cleansing or Not? NBER Working Paper 20427.

Giroud, Xavier, and Holger Mueller, 2016, Firm Leverage, Consumer Demand, and Employment Losses during the Great Recession, forthcoming, Quarterly Journal of Economics.

Glaeser, Edward, and Joshua Gottlieb, 2008, The Economics of Place-Making Policies, Brookings Papers on Economic Activity, 155-239.

Hess, Gregory, and Kwanho Shin, 1998, Intranational Business Cycles in the United States, Journal of International Economics 44, 289-313.

Hurst, Erik, Benjamin Keys, Amit Seru, and Joseph Vavra, 2016, Regional Redistribution through the U.S. Mortgage Market, forthcoming, American Economic Review.

Inderst, Roman, and Holger Mueller, 2003, Internal versus External Financing: An Optimal Contracting Approach, Journal of Finance 58, 1033-1062.

Jarmin, Ron, and Javier Miranda, 2002, The Longitudinal Business Database, CES Working Paper 02-17.

Kaplan, Steven, and Luigi Zingales, 1997, Do Financing Constraints Explain Why Investment Is Correlated with Cash Flow? Quarterly Journal of Economics 112, 169-215.

Kaplan, Greg, Kurt Mitman, and Giovanni Violante, 2016, Non-durable Consumption and Housing Net Worth in the Great Recession: Evidence from Easily Accessible Data, mimeo, Princeton University. 
Keys, Benjamin, Tomasz Piskorski, Amit Seru, and Vincent Yao, 2014, Mortgage Rates, Household Balance Sheets, and the Real Economy, mimeo, University of Chicago.

Kline, Patrick, and Enrico Moretti, 2013, Place Based Policies with Unemployment, American Economic Review: Papers \& Proceedings 103, 238-243.

Kline, Patrick, and Enrico Moretti, 2014a, Local Economic Development, Agglomeration Economies, and the Big Push: 100 Years of Evidence from the Tennessee Valley Authority, Quarterly Journal of Economics 129, 275-331.

Kline, Patrick, and Enrico Moretti, 2014b, People, Places and Public Policy: Some Simple Welfare Economics of Local Economic Development Programs, Annual Review of Economics 6, 629-662.

Lamont, Owen, 1997, Cash Flow and Investment: Evidence from Internal Capital Markets, Journal of Finance 52, 83-109.

Lewellen, Wilbur, 1971, A Pure Financial Rationale for the Conglomerate Merger, Journal of Finance 26, 521-537.

Lustig, Hanno, and Stijn Van Nieuwerburgh, 2010, How Much Does Household Collateral Constrain Regional Risk Sharing? Review of Economic Dynamics 13, 265-294.

McCue, Kristin, 2003, Matching Compustat Data to the SSEL, mimeo, Center for Economic Studies.

Mian, Atif, and Amir Sufi, 2011, House Prices, Home Equity-Based Borrowing, and the US Household Leverage Crisis, American Economic Review 101, 2132-2156.

Mian, Atif, and Amir Sufi, 2014, What Explains the 2007-2009 Drop in Employment? Econometrica 82, 2197-2223.

Mian, Atif, Kamalesh Rao, and Amir Sufi, 2013, Household Balance Sheets, Consumption, and the Economic Slump, Quarterly Journal of Economics 128, 1-40.

Mian, Atif, Amir Sufi, and Francesco Trebbi, 2015, Foreclosures, House Prices, and the Real Economy, Journal of Finance 70, 2587-2634.

Moretti, Enrico, 2014, Local Labor Markets, in: Handbook of Labor Economcis, edited by David Card and Orley Ashenfelter. Amsterdam: North-Holland. 
Notowidigdo, Matthew, 2013, The Incidence of Local Labor Demand Shocks, mimeo, Northwestern University.

Peek, Joe, and Eric Rosengren, 1997, The International Transmission of Financial Shocks: The Case of Japan, American Economic Review 87, 495-505.

Peek, Joe, and Eric Rosengren, 2000, Collateral Damage: Effects of the Japanese Bank Crisis on Real Activity in the United States, American Economic Review 90, 30-45.

Saiz, Albert, 2010, The Geographic Determinants of Housing Supply, Quarterly Journal of Economics 125, 1253-1296.

Schnabl, Philipp, 2012, The International Transmission of Bank Liquidity Shocks: Evidence from an Emerging Market, Journal of Finance 67, 897-932.

Stein, Jeremy, 1997, Internal Capital Markets and the Competition for Corporate Resources, Journal of Finance 52, 111-133.

Stein, Jeremy, 2003, Agency, Information and Corporate Investment, in: Handbook of the Economics of Finance, edited by George Constantinides, Milton Harris, and René Stulz. Amsterdam: North-Holland.

Stroebel, Johannes, and Joseph Vavra, 2015, House Prices, Local Demand, and Retail Prices, mimeo, New York University.

Whited, Toni, and Guojun Wu, 2006, Financial Constraints Risk, Review of Financial Studies 19, 531-559.

Yagan, Danny, 2016, The Enduring Employment Impact of Your Great Recession Location, mimeo, UC Berkeley. 


\section{Figure I \\ Non-Tradable Establishment-Level Employment}

This figure plots the relationship between changes in non-tradable employment at the firm-county ("establishment”) level, $\Delta \log (E m p)$ 07-09, and either changes in county-level house prices, $\Delta \log (\mathrm{HP})_{06-09}$, or changes in house prices in other counties in which the firm has establishments, $\Delta \log (\mathrm{HP})_{06-09}$ (other). The sample is restricted to multi-county firms. To filter out any confounding effects of $\Delta \log (\mathrm{HP})_{06-09}$ (other) when plotting the relationship between $\Delta \log (\mathrm{Emp})_{07-09}$ and $\Delta \log (\mathrm{HP})_{06-09}$, we compute the residuals from a regression of $\Delta \log (E m p)_{07-09}$ on a constant and $\Delta \log (H P)_{06-09}$ (other). For each percentile of $\Delta \log (\mathrm{HP})_{06-09}$, the plot in the top panel shows the mean values of the residuals and $\Delta \log (\mathrm{HP})_{06-09}$, respectively. We proceed analogously in the bottom panel when plotting the relationship between $\Delta \log (\mathrm{Emp})_{07-09}$ and $\Delta \log (\mathrm{HP})_{06-09}$ (other).
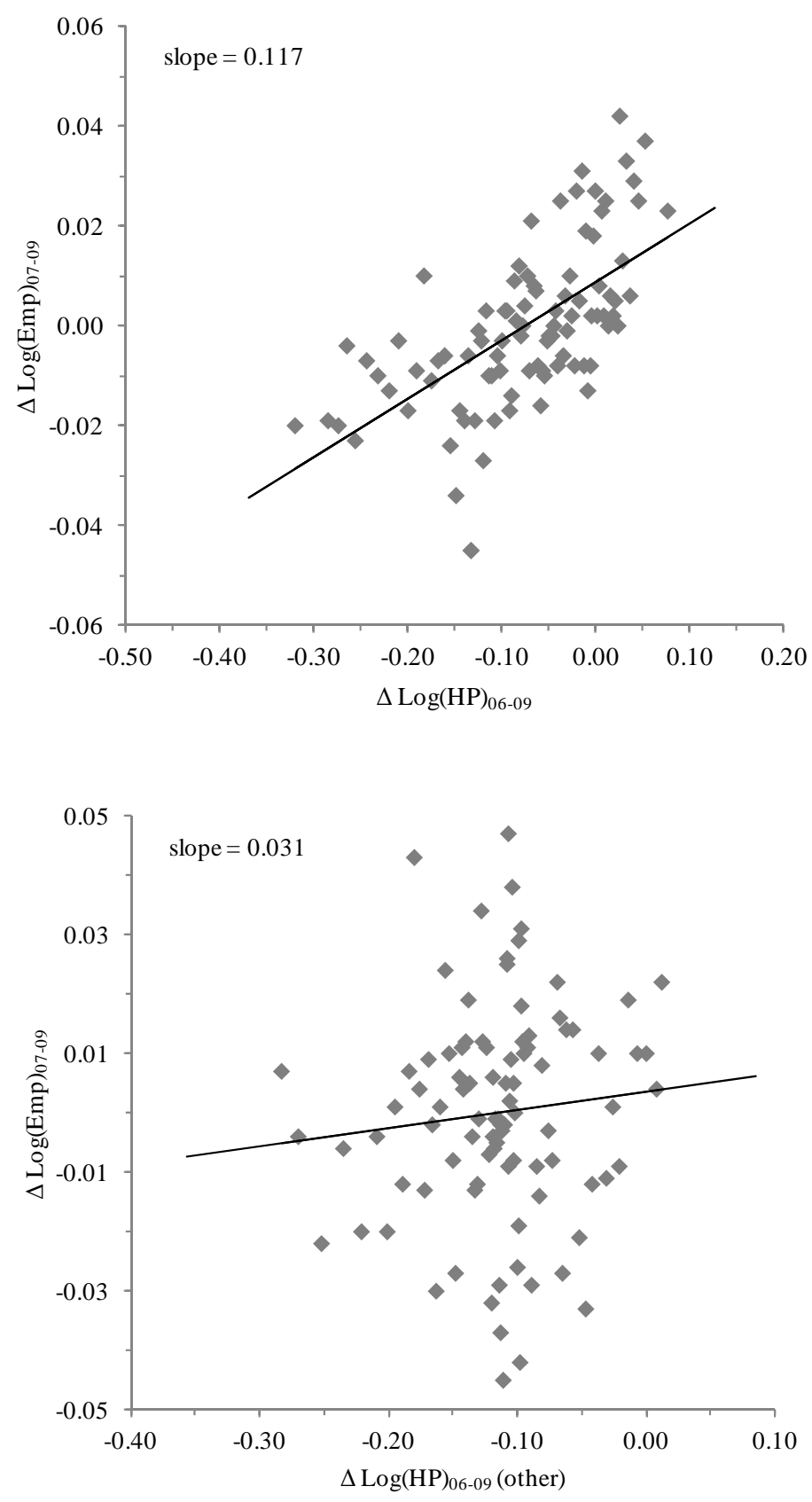
Figure II

Non-Tradable County-Level Employment

This figure is similar to Figure I, except that it plots the relationship between changes in non-tradable employment at the county level, $\Delta \log (E m p) 07-09$, and either changes in county-level house prices, $\Delta \log (\mathrm{HP})_{06-09}$, or changes in house prices in other counties linked through firms' internal networks of establishments, $\Delta \log (\mathrm{HP})_{06-09}$ (other). Non-tradable county-level employment is based on all firms in a county, including single-county firms.
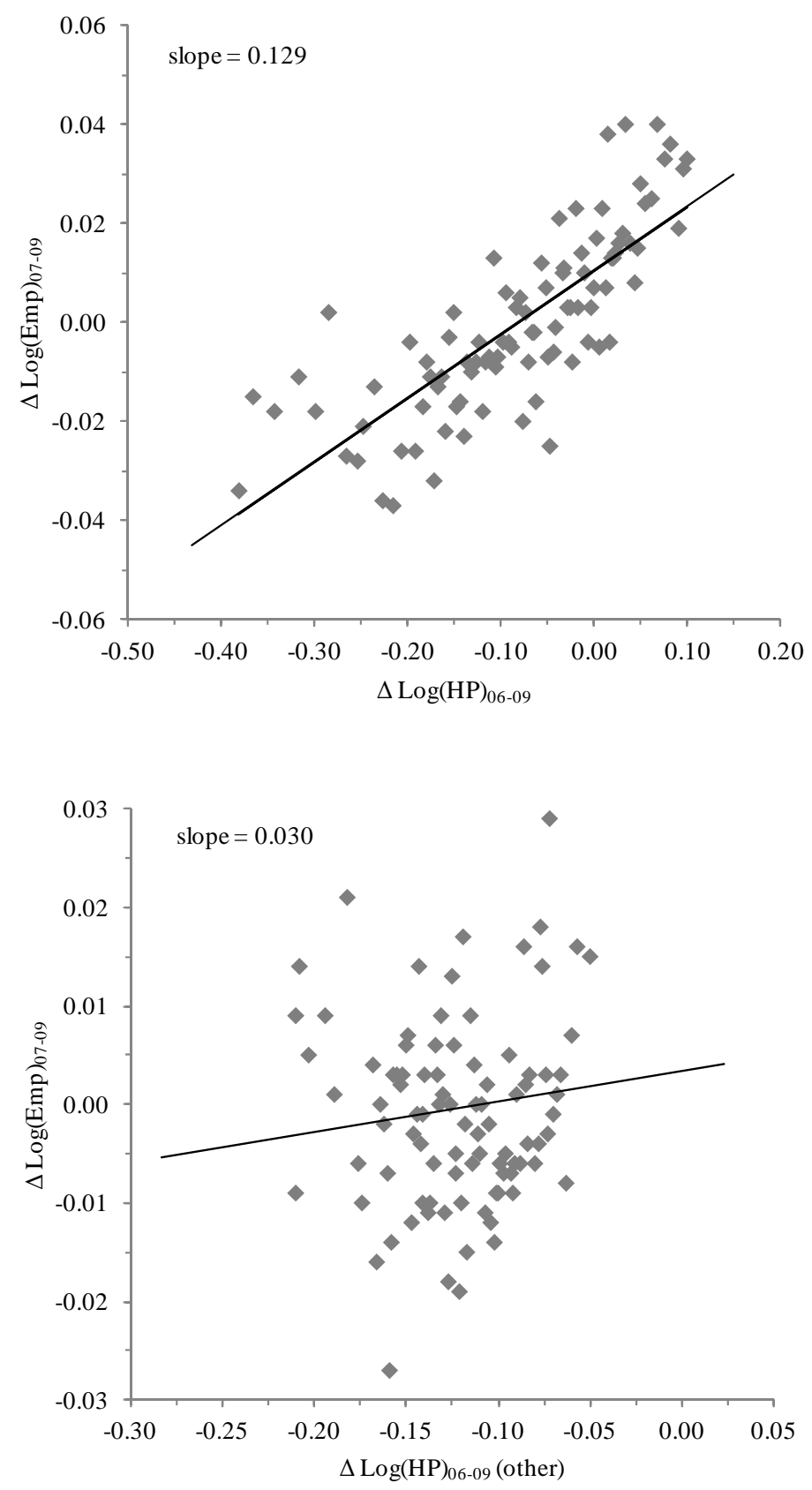
Figure III

Tradable County-Level Employment

This figure is similar to Figure II, except that it depicts tradable employment at the county level.
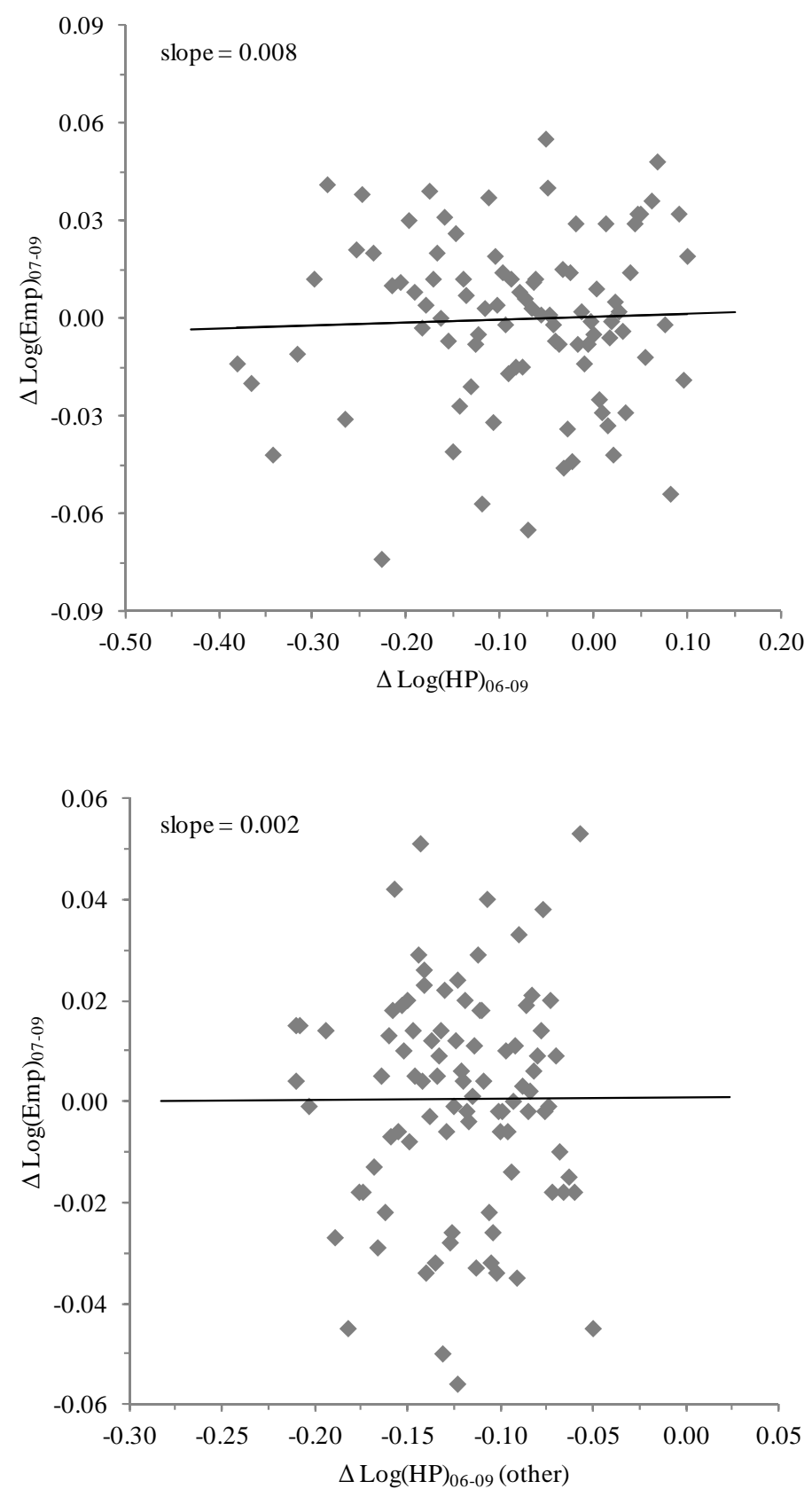


\section{Table I \\ Summary Statistics}

Panel (A) provides summary statistics at either the firm-county ("establishment”) or county level. The firm-county statistics (upper part of panel) pertain to multi-county firms operating in the non-tradable sector. Employees is the number of employees in 2006. $\Delta \log (E m p)_{07-09}$ is the percentage change in employment from 2007 to 2009. $\Delta \log (\mathrm{HP})_{06-09}$ is the percentage change in county-level house prices from 2006 to 2009. \# Linkages is the number of other counties in which the firm has establishments. All percentages are weighted by firm-county employment. The county-level statistics (bottom part of panel) pertain to all firms operating in the non-tradable sector, including single-county firms. Establishments and Employees is the number of establishments and employees, respectively, in 2006. Employment share is the ratio of non-tradable county-level employment to total county-level employment in 2006. $\Delta \log (E m p)_{07-09}$ is the percentage change in non-tradable countylevel employment from 2007 to 2009. $\Delta \log (\mathrm{HP})_{06-09}$ is the percentage change in county-level house prices from 2006 to 2009. Linkages ( $\geq X$ employees) is the number of other counties in 2006 in which non-tradable firms operating in a given county have at least X employees. All percentages are weighted by county-level employment. Panel (B) provides correlations between county-level linkage weights based on firms' internal networks of establishments (see Section 2.2) and either county or county-pair characteristics. Proximity is the inverse of the geographic distance between counties' centroids using the great circle distance formula. Similarity refers to the absolute difference between counties with respect to a given county-level characteristic. Age is the median age among county residents in 2000. Education is the percentage of adults in a county with a bachelor's degree or higher in 2000. Income is adjusted gross income per capita in 2006. Mortgage debt, mortgage delinquencies, and household debt (mortgage, auto, and credit card debt) are all per capita in 2006. *, **, and *** denotes significance at the $10 \%, 5 \%$, and $1 \%$ level, respectively.

Panel (A): Basic summary statistics

\begin{tabular}{|c|c|c|c|}
\hline & $\mathrm{N}$ & Mean & Std. Dev. \\
\hline \multicolumn{4}{|c|}{ Firm-county level (non-tradable multi-county firms) } \\
\hline Employees & 138,500 & 75.9 & 262.9 \\
\hline$\Delta \log (\text { Emp })_{07-09}$ & 138,500 & -0.029 & 1.003 \\
\hline$\Delta \log (\mathrm{HP})_{06-09}$ & 138,500 & -0.145 & 1.364 \\
\hline \# Linkages & 138,500 & 192.5 & 232.4 \\
\hline \multicolumn{4}{|c|}{ County level (all non-tradable firms) } \\
\hline Establishments & 1,000 & 1,074 & 2,174 \\
\hline Employees & 1,000 & 18,490 & 38,227 \\
\hline Employment share & 1,000 & 0.186 & 0.531 \\
\hline$\Delta \log (E m p)_{07-09}$ & 1,000 & -0.036 & 0.883 \\
\hline$\Delta \log (\mathrm{HP})_{06-09}$ & 1,000 & -0.145 & 0.189 \\
\hline Linkages ( $\geq 10$ Emp) & 1,000 & 980 & 175 \\
\hline Linkages ( $\geq 100$ Emp) & 1,000 & 867 & 235 \\
\hline Linkages ( $\geq 1,000$ Emp) & 1,000 & 480 & 198 \\
\hline
\end{tabular}


Table I

(continued)

Panel (B): Correlation with county-level linkage weights

\begin{tabular}{lcc}
\hline & Correlation & $p$-value \\
\cline { 2 - 3 } & & \\
\cline { 2 - 3 } Proximity & $0.103^{* * *}$ & 0.009 \\
Population & $0.073^{*}$ & 0.068 \\
Similarity & & \\
Income & & \\
Education & 0.028 & 0.210 \\
Age & -0.030 & 0.201 \\
Mortgage debt & -0.027 & 0.220 \\
Mortgage delinquencies & -0.006 & 0.860 \\
Household debt & -0.023 & 0.458 \\
$\Delta$ Log(HP) $06-09$ & -0.024 & 0.467 \\
& 0.018 & 0.290 \\
\hline
\end{tabular}




\section{Table II}

\section{Redistribution of Local Labor Market Shocks through Firms’ Internal Networks: Establishment-Level Evidence}

The dependent variable is the percentage change in non-tradable establishment-level employment from 2007 to 2009, $\Delta$ Log(Emp)07-09. In columns (1) to (3), establishments are aggregated at the firm-county level. In columns (4) to (6), establishments are aggregated at the firm-county-industry level. Industries are based on four-digit NAICS codes. $\triangle \log (\mathrm{HP})_{06-09}$ is the percentage change in county-level house prices from 2006 to $2009 . \Delta \mathrm{Log}(\mathrm{HP})_{06-09}$ (other) is the linkage-weighted percentage change in house prices from 2006 to 2009 in other counties in which the firm has establishments. Establishment-level linkage weights are described in Section 2.2. County $\times$ industry controls are the county-specific employment shares of all 23 two-digit NAICS industries in 2006. The sample is restricted to multi-county firms. All regressions are weighted by either firm-county employment (columns (1) to (3)) or firm-county-industry employment (columns (4) to (6)). Standard errors (in parentheses) are clustered at both the firm and county level. *, **, and *** denotes significance at the $10 \%, 5 \%$, and $1 \%$ level, respectively.

$\Delta \log (E m p){ }_{07-09}$

\begin{tabular}{|c|c|c|c|c|c|}
\hline \multicolumn{3}{|c|}{ Firm-county level } & \multicolumn{3}{|c|}{ Firm-county-industry level } \\
\hline (1) & $(2)$ & (3) & (4) & (5) & (6) \\
\hline $0.104 * * *$ & $0.092 * * *$ & & $0.105 * * *$ & $0.094 * * *$ & \\
\hline \multirow[t]{3}{*}{$(0.014)$} & $(0.015)$ & & $(0.016)$ & $(0.016)$ & \\
\hline & $0.029 * * *$ & $0.027 * * *$ & & $0.027 * * *$ & $0.028 * * *$ \\
\hline & $(0.010)$ & $(0.010)$ & & $(0.010)$ & $(0.009)$ \\
\hline Yes & Yes & - & Yes & Yes & - \\
\hline No & No & Yes & No & No & - \\
\hline No & No & No & No & No & Yes \\
\hline 0.01 & 0.01 & 0.03 & 0.01 & 0.01 & 0.11 \\
\hline 138,500 & 138,500 & 138,500 & 161,700 & 161,700 & 161,700 \\
\hline
\end{tabular}

County $\times$ industry controls

County fixed effects

County $\times$ industry fixed effects

R-squared

138,500

138,500

138,500

161,700

(2)




\section{Table III}

\section{Financial Constraints}

This table presents variants of the regression in column (3) of Table II in which $\Delta \log (\mathrm{HP})_{06-09}$ and $\Delta \log (\mathrm{HP})_{06-09}$ (other) are interacted with measures of firms' financial constraints (FC) in 2006. In column (1), FC is firm leverage, which is the ratio of the sum of debt in current liabilities and long-term debt to total assets. In column (2), FC is the financial constraints index of Kaplan and Zingales (1997). In column (3), FC is the financial constraints index of Whited and Wu (2006). Both financial constraints indices are net of their minimum values. The sample is restricted to multi-county firms that have a match in Compustat. All regressions are weighted by firm-county employment. Standard errors (in parentheses) are clustered at both the firm and county level. *, **, and *** denotes significance at the $10 \%, 5 \%$, and $1 \%$ level, respectively.

\begin{tabular}{|c|c|c|c|}
\hline & \multicolumn{3}{|c|}{$\Delta \log ($ Emp)07-09 } \\
\hline & Leverage 06 & KZ-index06 & WW-index06 \\
\hline & (1) & $(2)$ & (3) \\
\hline \multirow[t]{2}{*}{$\Delta \log (\mathrm{HP})_{06-09} \times \mathrm{FC}$} & $0.133^{* *}$ & $0.003^{* *}$ & $0.046^{* *}$ \\
\hline & $(0.066)$ & $(0.001)$ & $(0.020)$ \\
\hline \multirow[t]{2}{*}{$\Delta$ Log(HP)06-09 (other) } & 0.011 & 0.009 & 0.011 \\
\hline & $(0.007)$ & $(0.009)$ & $(0.010)$ \\
\hline \multirow[t]{2}{*}{$\Delta$ Log(HP)06-09 (other) $\times$ FC } & $0.036 * *$ & $0.001 * *$ & $0.011^{* *}$ \\
\hline & $(0.018)$ & $(0.000)$ & $(0.006)$ \\
\hline \multirow[t]{2}{*}{ FC } & $-0.037 * * *$ & $-0.002 * *$ & $-0.008 * *$ \\
\hline & $(0.008)$ & $(0.001)$ & $(0.004)$ \\
\hline County fixed effects & Yes & Yes & Yes \\
\hline R-squared & 0.04 & 0.04 & 0.04 \\
\hline Observations & 40,100 & 40,100 & 40,100 \\
\hline
\end{tabular}


Table IV

\section{Scope of Firms' Regional Networks}

This table presents variants of the regression in column (3) of Table II in which $\Delta \log (\mathrm{HP})_{06-09}$ is interacted with measures of the scope of firms' regional networks (RN) in 2006. In columns (1) and (4), RN is a dummy variable indicating whether the firm operates in multiple counties. In columns (2) and (5), RN is the logarithm of the number of counties in which the firm operates. In columns (3) and (6), RN is one minus the Herfindahl-Hirschman index (HHI) measuring the extent of the firm's geographic concentration based on its non-tradable employment at the county level. Size is the logarithm of the number of employees of the firm. The sample in columns (2), (3), (5), and (6) is restricted to multi-county firms. All regressions are weighted by firm-county employment. Standard errors (in parentheses) are clustered at both the firm and county level. *, **, and *** denotes significance at the $10 \%, 5 \%$, and $1 \%$ level, respectively.

\begin{tabular}{|c|c|c|c|c|c|c|}
\hline & \multicolumn{6}{|c|}{$\Delta \log (\mathrm{Emp})_{07-09}$} \\
\hline & Multi-county & \# Counties & Geogr. HHI & Multi-county & \# Counties & Geogr. HHI \\
\hline & (1) & (2) & (3) & (4) & (5) & (6) \\
\hline$\Delta \log (\mathrm{HP})_{06-09} \times \mathrm{RN}$ & $\begin{array}{c}-0.052 * * * \\
(0.017)\end{array}$ & $\begin{array}{c}-0.019 * * * \\
(0.006)\end{array}$ & $\begin{array}{c}-0.217 * * * \\
(0.070)\end{array}$ & $\begin{array}{c}-0.043 * * \\
(0.020)\end{array}$ & $\begin{array}{c}-0.016 * * * \\
(0.005)\end{array}$ & $\begin{array}{c}-0.209 * * \\
(0.101)\end{array}$ \\
\hline $\mathrm{RN}$ & $\begin{array}{c}0.011^{* * *} \\
(0.002)\end{array}$ & $\begin{array}{c}0.006 * * * \\
(0.001)\end{array}$ & $\begin{array}{c}0.042 * * * \\
(0.008)\end{array}$ & $\begin{array}{c}0.010 * * * \\
(0.002)\end{array}$ & $\begin{array}{c}0.005^{* * *} \\
(0.001)\end{array}$ & $\begin{array}{l}0.017 * \\
(0.010)\end{array}$ \\
\hline$\Delta \log (\mathrm{HP})_{06-09} \times$ Size & & & & $\begin{array}{c}-0.002 * * * \\
(0.000)\end{array}$ & $\begin{array}{c}-0.002 * * \\
(0.001)\end{array}$ & $\begin{array}{c}-0.003 * * * \\
(0.001)\end{array}$ \\
\hline Size & & & & $\begin{array}{c}0.003 * * * \\
(0.001)\end{array}$ & $\begin{array}{c}0.008 * * * \\
(0.001)\end{array}$ & $\begin{array}{c}0.009 * * * \\
(0.001)\end{array}$ \\
\hline County fixed effects & Yes & Yes & Yes & Yes & Yes & Yes \\
\hline R-squared & 0.01 & 0.03 & 0.03 & 0.01 & 0.03 & 0.03 \\
\hline Observations & 669,700 & 138,500 & 138,500 & 669,700 & 138,500 & 138,500 \\
\hline
\end{tabular}


Table V

\section{Aggregate Non-Tradable Employment at the County Level}

The dependent variable is the percentage change in non-tradable county-level employment from 2007 to $2009, \Delta$ Log(Emp) $07-09 . \Delta$ Log(HP) 06 -09 is the percentage change in county-level house prices from 2006 to 2009. $\Delta$ Log(HP)06-09 (other) is the linkage-weighted percentage change in house prices from 2006 to 2009 in other counties linked through firms' internal networks of establishments. County-level linkage weights are described in Section 2.2. In column (3), equal weight is assigned to all other counties. In column (4), equal weight is assigned to a randomly selected sample of 1,000 counties (with replacement). In column (5), linkage weights are randomly assigned from the population of actual linkage weights (with replacement). In column (6), linkage weights are based on tradable firms' internal networks of establishments. County $\times$ industry controls are the county-specific employment shares of all 23 two-digit NAICS industries in 2006. All regressions are weighted by county-level employment. Standard errors (in parentheses) are clustered at the state level. *, **, and *** denotes significance at the $10 \%, 5 \%$, and $1 \%$ level, respectively.

\begin{tabular}{|c|c|c|c|c|c|c|}
\hline & \multicolumn{6}{|c|}{$\Delta \log (E m p)_{07-09}$} \\
\hline & \multirow[b]{2}{*}{$(1)$} & \multirow[b]{2}{*}{$(2)$} & \multicolumn{4}{|c|}{ Placebo tests } \\
\hline & & & (3) & (4) & (5) & (6) \\
\hline$\Delta \log (\mathrm{HP})_{06-09}$ & $\begin{array}{c}0.122 * * * \\
(0.006)\end{array}$ & $\begin{array}{c}0.115^{* * *} \\
(0.012)\end{array}$ & $\begin{array}{c}0.123 * * * \\
(0.006)\end{array}$ & $\begin{array}{c}0.123 * * * \\
(0.006)\end{array}$ & $\begin{array}{c}0.122 * * * \\
(0.006)\end{array}$ & $\begin{array}{c}0.122 * * * \\
(0.006)\end{array}$ \\
\hline$\Delta \log (\mathrm{HP})_{06-09}$ (other) & & $\begin{array}{c}0.024 * * * \\
(0.007)\end{array}$ & & & & \\
\hline$\Delta \log (\mathrm{HP})_{06-09}$ (other, equal weights) & & & $\begin{array}{c}0.007 \\
(0.039)\end{array}$ & & & \\
\hline$\Delta \log (\mathrm{HP})_{06-09}$ (other, random counties) & & & & $\begin{array}{c}0.003 \\
(0.028)\end{array}$ & & \\
\hline$\Delta \log (\mathrm{HP})_{06-09}$ (other, random linkages) & & & & & $\begin{array}{c}0.002 \\
(0.024)\end{array}$ & \\
\hline$\Delta \log (\mathrm{HP})_{06-09}$ (other, tradable firms) & & & & & & $\begin{array}{c}0.004 \\
(0.010)\end{array}$ \\
\hline County $\times$ industry controls & Yes & Yes & Yes & Yes & Yes & Yes \\
\hline R-squared & 0.16 & 0.17 & 0.16 & 0.16 & 0.16 & 0.16 \\
\hline Observations & 1,000 & 1,000 & 1,000 & 1,000 & 1,000 & 1,000 \\
\hline
\end{tabular}


Table VI

\section{Direct Demand Spillovers}

This table presents variants of the regression in column (2) of Table V. $\Delta$ Log(HP)06-09 (other, proximity) is similar to $\Delta$ Log(HP) 06 -09 (other), except that linkage weights are based on the inverse of the geographic distance between counties' centroids using the great circle distance formula. $\Delta$ Log(HP) $06-09$ (other, excl. adj. counties) is similar to $\Delta \log (\mathrm{HP})_{06-09}$ (other), except that linkage weights are set to zero for adjacent counties. $\Delta \log (\mathrm{HP})_{06-09}$ (other, counties $\geq \mathrm{X}$ miles) is similar to $\Delta$ Log(HP) $06-09$ (other), except that linkage weights are set to zero for counties whose centroid is less than X miles away from the county's own centroid. All regressions are weighted by county-level employment. Standard errors (in parentheses) are clustered at the state level. *, **, and $* * *$ denotes significance at the $10 \%$, $5 \%$, and $1 \%$ level, respectively.

\begin{tabular}{|c|c|c|c|c|c|c|}
\hline & \multicolumn{6}{|c|}{$\Delta \log (E m p)_{07-09}$} \\
\hline & $(1)$ & $(2)$ & (3) & (4) & (5) & (6) \\
\hline$\Delta \log (\mathrm{HP})_{06-09}$ & $\begin{array}{c}0.111^{* * *} \\
(0.012)\end{array}$ & $\begin{array}{c}0.115^{* * *} \\
(0.012)\end{array}$ & $\begin{array}{c}0.115 * * * \\
(0.012)\end{array}$ & $\begin{array}{c}0.116^{* * *} \\
(0.012)\end{array}$ & $\begin{array}{c}0.116^{* * *} \\
(0.012)\end{array}$ & $\begin{array}{c}0.116 * * * \\
(0.012)\end{array}$ \\
\hline$\Delta \log (\mathrm{HP})_{06-09}$ (other, proximity) & $\begin{array}{c}0.012 * \\
(0.007)\end{array}$ & & & & & \\
\hline$\Delta \log (\mathrm{HP})_{06-09}$ (other) & $\begin{array}{c}0.019 * * * \\
(0.007)\end{array}$ & & & & & \\
\hline$\Delta \log (\mathrm{HP})_{06-09}$ (other, excl. adj. counties) & & $\begin{array}{c}0.020 * * * \\
(0.006)\end{array}$ & & & & \\
\hline$\Delta \log (\mathrm{HP})_{06-09}$ (other, counties $\geq 50$ miles) & & & $\begin{array}{c}0.019 * * * \\
(0.006)\end{array}$ & & & \\
\hline$\Delta \log (H P)_{06-09}$ (other, counties $\geq 100$ miles) & & & & $\begin{array}{c}0.019 * * * \\
(0.006)\end{array}$ & & \\
\hline$\Delta \log (\mathrm{HP})_{06-09}$ (other, counties $\geq 150$ miles) & & & & & $\begin{array}{c}0.018^{* * *} \\
(0.006)\end{array}$ & \\
\hline$\Delta \log (\mathrm{HP})_{06-09}$ (other, counties $\geq 250$ miles) & & & & & & $\begin{array}{c}0.017 * * * \\
(0.006)\end{array}$ \\
\hline County $\times$ industry controls & Yes & Yes & Yes & Yes & Yes & Yes \\
\hline R-squared & 0.17 & 0.17 & 0.17 & 0.17 & 0.17 & 0.17 \\
\hline Observations & 1,000 & 1,000 & 1,000 & 1,000 & 1,000 & 1,000 \\
\hline
\end{tabular}


Table VII

\section{Common County-Level Shocks}

This table presents variants of the regression in column (2) of Table V. $\Delta \log (\mathrm{HP})_{06-09}$ (other, *) is similar to $\Delta \log (\mathrm{HP})_{06-09}$ (other), except that linkage weights are based on the inverse of the absolute difference between counties with respect to either income, age, education, mortgage debt, mortgage delinquencies, household debt, or $\Delta$ Log(HP) $06-09$ (other). All of these county-level characteristics are described in Table I. All regressions are weighted by county-level employment. Standard errors (in parentheses) are clustered at the state level. *, **, and *** denotes significance at the $10 \%, 5 \%$, and $1 \%$ level, respectively.

\begin{tabular}{|c|c|c|c|c|c|c|c|}
\hline & \multicolumn{7}{|c|}{$\Delta \log (E m p)_{07-09}$} \\
\hline & (1) & $(2)$ & (3) & (4) & (5) & (6) & (7) \\
\hline$\Delta \log (\mathrm{HP})_{06-09}$ & $\begin{array}{c}0.112 * * * \\
(0.012)\end{array}$ & $\begin{array}{c}0.114 * * * \\
(0.012)\end{array}$ & $\begin{array}{c}0.108 * * * \\
(0.012)\end{array}$ & $\begin{array}{c}0.114^{* * * *} \\
(0.012)\end{array}$ & $\begin{array}{c}0.114 * * * \\
(0.012)\end{array}$ & $\begin{array}{c}0.115^{* * * *} \\
(0.012)\end{array}$ & $\begin{array}{c}0.115^{* * *} \\
(0.012)\end{array}$ \\
\hline$\Delta \log (\mathrm{HP})_{06-09}$ (other) & $\begin{array}{c}0.025 * * * \\
(0.007)\end{array}$ & $\begin{array}{c}0.025 * * * \\
(0.007)\end{array}$ & $\begin{array}{c}0.029 * * * \\
(0.008)\end{array}$ & $\begin{array}{c}0.027 * * * \\
(0.007)\end{array}$ & $\begin{array}{c}0.024 * * * \\
(0.007)\end{array}$ & $\begin{array}{c}0.024 * * * \\
(0.007)\end{array}$ & $\begin{array}{c}0.023 * * * \\
(0.007)\end{array}$ \\
\hline$\Delta \log (\mathrm{HP})_{06-09}$ (other, income) & $\begin{array}{c}0.003 \\
(0.015)\end{array}$ & & & & & & \\
\hline$\Delta \log (\mathrm{HP})_{06-09}$ (other, education) & & $\begin{array}{c}0.004 \\
(0.010)\end{array}$ & & & & & \\
\hline$\Delta \log (\mathrm{HP})_{06-09}$ (other, age) & & & $\begin{array}{c}0.003 \\
(0.013)\end{array}$ & & & & \\
\hline$\Delta \log (\mathrm{HP})_{06-09}$ (other, mortgage debt) & & & & $\begin{array}{c}0.003 \\
(0.014)\end{array}$ & & & \\
\hline$\Delta \log (\mathrm{HP})_{06-09}$ (other, mortgage delinq.) & & & & & $\begin{array}{c}0.002 \\
(0.013)\end{array}$ & & \\
\hline$\Delta \log (\mathrm{HP})_{06-09}$ (other, household debt) & & & & & & $\begin{array}{c}0.000 \\
(0.013)\end{array}$ & \\
\hline$\Delta \log (\mathrm{HP})_{06-09}$ (other, house prices) & & & & & & & $\begin{array}{c}0.004 \\
(0.012)\end{array}$ \\
\hline County $\times$ industry controls & Yes & Yes & Yes & Yes & Yes & Yes & Yes \\
\hline R-squared & 0.17 & 0.17 & 0.17 & 0.17 & 0.17 & 0.17 & 0.17 \\
\hline Observations & 1,000 & 1,000 & 1,000 & 1,000 & 1,000 & 1,000 & 1,000 \\
\hline
\end{tabular}


Table VIII

Instrumenting House Price Changes

This table presents variants of the regression in column (2) of Table V in which $\Delta \log (\mathrm{HP})_{06-09}$ and $\Delta \log (\mathrm{HP})_{06-09}$ (other) are instrumented using the county's housing supply elasticity and the linkage-weighted housing supply elasticity in other counties linked through firms' internal networks, respectively. County-level linkage weights are described in Section 2.2. In columns (4) to (6), the "share of unavailable land" is used in lieu of housing supply elasticity. Both instruments are described in Saiz (2010). All regressions are weighted by county-level employment. Standard errors (in parentheses) are clustered at the state level. *, **, and *** denotes significance at the $10 \%$, $5 \%$, and $1 \%$ level, respectively.

\begin{tabular}{|c|c|c|c|c|c|c|}
\hline & \multicolumn{3}{|c|}{ Housing supply elasticity } & \multicolumn{3}{|c|}{ Share of unavailable land } \\
\hline & \multicolumn{2}{|c|}{ First stage } & \multirow{2}{*}{$\begin{array}{c}\text { Second stage } \\
\Delta \text { Log(Emp })_{07-09}\end{array}$} & \multicolumn{2}{|c|}{ First stage } & \multirow{2}{*}{$\begin{array}{c}\text { Second stage } \\
\Delta \log (\text { Emp })_{07-09}\end{array}$} \\
\hline & $\Delta \log (\mathrm{HP})_{06-09}$ & $\begin{array}{l}\Delta \log (\mathrm{HP})_{06-09} \\
\quad \text { (other) }\end{array}$ & & $\Delta \log (\mathrm{HP})_{06-09}$ & $\begin{array}{l}\Delta \log (H P)_{06-09} \\
\text { (other) }\end{array}$ & \\
\hline & $(1)$ & $(2)$ & (3) & (4) & (5) & (6) \\
\hline Housing supply elasticity & $\begin{array}{c}0.069 * * * \\
(0.010)\end{array}$ & $\begin{array}{c}0.001 \\
(0.014)\end{array}$ & & & & \\
\hline Housing supply elasticity (other) & $\begin{array}{c}0.016 \\
(0.013)\end{array}$ & $\begin{array}{c}0.068 * * * \\
(0.011)\end{array}$ & & & & \\
\hline Share of unavailable land & & & & $\begin{array}{c}-0.303^{* * *} \\
(0.084)\end{array}$ & $\begin{array}{l}-0.008 \\
(0.078)\end{array}$ & \\
\hline Share of unavailable land (other) & & & & $\begin{array}{l}-0.038 \\
(0.070)\end{array}$ & $\begin{array}{c}-0.294^{* * *} \\
(0.082)\end{array}$ & \\
\hline$\Delta \log (\mathrm{HP})_{06-09}$ & & & $\begin{array}{c}0.114 * * * \\
(0.016)\end{array}$ & & & $\begin{array}{c}0.110 * * * \\
(0.015)\end{array}$ \\
\hline$\Delta \log (\mathrm{HP})_{06-09}$ (other) & & & $\begin{array}{c}0.024 * * \\
(0.010)\end{array}$ & & & $\begin{array}{c}0.025 * * \\
(0.010)\end{array}$ \\
\hline County $\times$ industry controls & Yes & Yes & Yes & Yes & Yes & Yes \\
\hline R-squared & 0.52 & 0.62 & 0.18 & 0.50 & 0.62 & 0.18 \\
\hline Observations & 700 & 700 & 700 & 700 & 700 & 700 \\
\hline
\end{tabular}




\section{Table IX}

\section{Counties in Which House Prices Did Not Fall}

This table presents variants of the regressions in columns (1) and (2) of Table V in which the sample is restricted to counties in which house prices either increased (columns (1) and (2)) or changed only little, defined as a change of less than \pm 2.5 percent (columns (3) and (4)). All regressions are weighted by county-level employment. Standard errors (in parentheses) are clustered at the state level. *, **, and $* * *$ denotes significance at the $10 \%, 5 \%$, and $1 \%$ level, respectively.

\begin{tabular}{|c|c|c|c|c|}
\hline & \multicolumn{4}{|c|}{$\Delta \log (\text { Emp })_{07-09}$} \\
\hline & \multicolumn{2}{|c|}{$\Delta \log (\mathrm{HP})_{06-09}>0$} & \multicolumn{2}{|c|}{$\Delta \log (\mathrm{HP})_{06-09} \pm 0.025$} \\
\hline & $(1)$ & (2) & (3) & (4) \\
\hline$\Delta \log (\mathrm{HP})_{06-09}$ & $\begin{array}{c}0.018 \\
(0.050)\end{array}$ & $\begin{array}{c}0.014 \\
(0.051)\end{array}$ & $\begin{array}{c}0.001 \\
(0.012)\end{array}$ & $\begin{array}{c}0.001 \\
(0.012)\end{array}$ \\
\hline$\Delta$ Log(HP) $)_{06-09}$ (other) & & $\begin{array}{c}0.019 * * \\
(0.010)\end{array}$ & & $\begin{array}{c}0.020 * * \\
(0.010)\end{array}$ \\
\hline County $\times$ industry controls & Yes & Yes & Yes & Yes \\
\hline R-squared & 0.18 & 0.19 & 0.22 & 0.23 \\
\hline Observations & 200 & 200 & 200 & 200 \\
\hline
\end{tabular}




\section{Table X \\ Trade Channel}

This table presents variants of the regression in column (2) of Table V. In column (1), the dependent variable is the percentage change in tradable county-level employment from 2007 to 2009, $\Delta \log (\mathrm{Emp})_{07-09}$. In column (2), $\Delta \log (\mathrm{HP})_{06-09}$ (other, population) is similar to $\Delta \log (\mathrm{HP})_{06-09}$ (other), except that linkage weights are based on counties' shares of the total U.S. population. All regressions are weighted by county-level employment. Standard errors (in parentheses) are clustered at the state level. *, **, and *** denotes significance at the $10 \%, 5 \%$, and $1 \%$ level, respectively.

\begin{tabular}{lcc}
\hline & \multicolumn{2}{c}{$\Delta \log (\text { Emp })_{07-09}$} \\
\cline { 2 - 3 } & Tradable & Non-tradable \\
& $(1)$ & $(2)$ \\
\cline { 2 - 3 }$\Delta \log (\mathrm{HP})_{06-09}$ & 0.011 & $0.114^{* * *}$ \\
& $(0.010)$ & $(0.012)$ \\
$\Delta \log (\mathrm{HP})_{06-09}$ (other) & 0.004 & $0.023^{* * *}$ \\
& $(0.014)$ & $(0.007)$ \\
$\Delta$ Log(HP) $)_{06-09}$ (other, population) & & 0.012 \\
& & $(0.010)$ \\
County $\times$ industry controls & Yes & Yes \\
R-squared & & 0.17 \\
Observations & 0.13 & 1,000 \\
\hline
\end{tabular}

